\title{
Tolerance to irrigation water salinity in Physalis peruviana L. plants ${ }^{1}$
}

\author{
Joseano Graciliano da Silva $* \mathbb{0}$, Odair Honorato de Oliveira ${ }^{3}$, Kilson Pinheiro Lopes ${ }^{3}$, \\ Jerffeson Araujo Cavalvante ${ }^{2}$, Nander Ferraz Hornke ${ }^{2}$, Dario Munt de Moraes ${ }^{2}$
}

$10.1590 / 0034-737 X 202168060014$

\begin{abstract}
Abiotic factors, such as saline stress, can happen in agricultural areas and can harm the metabolism of the plants. Studies that seek to evaluate the acting of P. peruviana L. under stress conditions are still incipient. Therefore, the objective was to evaluate the tolerance to salinity in plants of P. peruviana L. under different saline levels of irrigation water. The work was developed in the experimental farm of the Universidade Federal de Campina Grande, Campus Pombal, PB, from January to March 2017. Four saline concentrations of irrigation water were used (0.3; 1.2; 2.1 ; and $3.0 \mathrm{dS} \mathrm{m}^{-1}$ ) with five repetitions. At 60 days after the transplant, were evaluated the leaf area, intercellular $\mathrm{CO}_{2}$ concentration, stomatal conductance, transpiration, photosynthetic rate, intrinsic water use efficiency, instantaneous carboxylation efficiency, electrolyte extravasation, chlorophyll a, b and carotenoids. The results show that saline levels of irrigation water up to $3.0 \mathrm{dS} \mathrm{m}^{-1}$ did not provide physiological damages in plants of $P$. peruviana $\mathrm{L}$. until $60 \mathrm{DAT}$, except for extravasation of electrolytes and chlorophyll a and $\mathrm{b}$, characterizing the plant as tolerant to salinity until the studied level.
\end{abstract}

Keywords: physalis; salinity; gas exchange; water use efficiency.

\section{INTRODUCTION}

The Physalis peruviana L. is a vegetable fruit that has as the center of origin in countries like Bolivia, Colombia, Peru, and Ecuador (Muniz et al., 2011), while other authors report its production in certain areas of South Africa (Puente et al., 2011). In Brazil, concerning studies to $P$. peruviana $\mathrm{L}$. they are still incipient, having some works accomplished with this species, mainly in the coldest regions of the country (Lima, 2009; Muniz et al., 2015). Production data for the species in Brazil, despite being scarce, esteem values from two to three annual tons (Melo et al., 2017).

Referring to the productivity index observed in Brazil, many of the times, it can be related to the cultural handling used in field cultivation; that due to the physiologic alterations in the plant, provoked by abiotic factors, as observed by Ianckievicz et al. (2013), Zeist et al. (2014) and Lima et al. (2015). This way, when in stress conditions, the hormonal and metabolic alterations in the plant can result in unfavorable aspects to the production.

The amount of water supplied to the plants during the stages of, in agreement with Silva et al. (2015), on the ability of plants to perform gas exchange and photosynthesis, so that excess can affect root aeration and nutrient leaching, while lack of water can reduce growth and affect numerous physiological processes and, therefore, production.

Regarding the use of saline water in irrigation, Ianckievicz et al. (2013) report that plants of P. peruviana L., submitted to saline concentrations of nutrients corresponding to $3.0 \mathrm{dS} \mathrm{m}^{-1}$ presented a larger fresh mass of the fruits, while Campos e Cavalcante (2009) observed that the bell pepper (Capsicum annuиm L.) tolerates up to $1.88 \mathrm{dS} \mathrm{m}^{-1}$ of salts in irrigation water if bovine biofertilizer is used as a salinity attenuator.

\footnotetext{
Submitted on November 13 th, 2019 and accepted on September 09th, 2021.

${ }^{1}$ This work is part of the monograph of the first author's.

${ }^{2}$ Universidade Federal de Pelotas, Departamento de Fitotecnia, Pelotas, Rio Grande do Sul, Brazil. joseano_agronomo@outlook.com; jerffeson_agronomo@hotmail.com; nanderhornke@gmail.com; moraesdm@ufpel.edu.br

${ }^{3}$ Universidade Federal de Campina Grande, Pombal, Paraíba, Brazil. odair_games@hotmail.com; kilsonlopes@gmail.com

*Corresponding author: joseano_agronomo@outlook.com
} 
According to Dias and Blanco (2010), when under saline conditions, growth and fruit production are significantly reduced, which can be attributed to the effect of toxic ions present in the water and osmotic stress According to some authors, changes in morphology, anatomy, water relations, photosynthesis, hormonal profile, distribution of toxic ions and biochemical adaptation (such as the response of the antioxidative metabolism) are strategies adopted by plants, including vegetables, to tolerate the salt stress of irrigation water (Acosta-Motos, et al., 2017).

The Northeast area of Brazil presents a low rainfall index and high temperatures in certain periods (Silva et al., 2011), besides, a great part of underground water possesses a high content of salts in its composition, which can be an added difficulty in the production of $P$. peruviana $\mathrm{L}$., for instance. However, under conditions of saline stress, some plants can tolerate the salinity, such as the Atriplex nummularia (Melo et al., 2017), that gets to accumulate salts inside its cells, while others manage to exclude $\mathrm{Cl}^{-}$from the root system, or to accumulate these ions in the cell vacuole (Flowers \& Colmer, 2015), as well as to reduce the photosynthetic rate, water absorption or increase the osmotic potential, according to Lima et al. (2015) and Taiz et al. (2017). Besides, it is possible to observe mechanisms of exclusion of the elements sodium and chlorine in some morphophysiological structures in the plant (Deinlein et al., 2014).

In this context, this work aimed to evaluate the tolerance to salinity in plants of $P$. peruviana $\mathrm{L}$. under different saline levels of irrigation water.

\section{MATERIAL AND METHODS}

\section{Conduction and design of the experiment}

The study was developed in a protected atmosphere in the experimental farm of the Center for Agri-Food Science and Technology of the Federal University of Campina Grande, located in São Domingos' city, PB (648'41.7 “S of latitude and $37^{\circ} 56^{\prime} 13.8$ "W of longitude with an altitude of 190 meters) from January to March 2017, lasting 60 days. For the extraction of seeds, the fruits were cut in the middle with bistoury and the seeds were washed in running water with aid of a mesh sieve die for the complete removal of the pulp. Afterward, the seeds were put to dry in atmospheric conditions in the laboratory for three days on two sheets of Germitest paper.

The seedlings' production was accomplished according to the methodology described by Silva et al. (2018), adopting, therefore, polypropylene containers with a capacity of $50 \mathrm{ml}$, filled out with commercial substratum Basaplant $\AA$, sowed to $0,5 \mathrm{~cm}$ of depth and irrigated three times a day with water of urban provisioning $\left(0.3 \mathrm{dS} \mathrm{m}^{-1}\right)$ until the 30 days after the sowing (DAS) (Muniz et al., 2015), being transplanted for plastic vases with capacity for $12 \mathrm{dm}^{-3}$, however, containing 10 soil $\mathrm{dm}^{-3}$, sand and manure in the proportions $2: 1: 1$, the chemical and physical characteristics of the substratum used in the production of seedlings (SPM) and in the cultivation (SCV) of the plants they can be observed in Table 1 .

The water used in the irrigation was originating from an artesian well and the urban net, being mixed to obtain the electric conductivities $\left(0.3 ; 1.2 ; 2.1\right.$ and $\left.3.0 \mathrm{dS} \mathrm{m}^{-1}\right)$, its chemical characteristics are presented in Table 1 . The maximum level of $3.0 \mathrm{dS}$ was adopted due to the natural salinity in the artesian well, being close to this value. During the first seven days after the transplant, it was applied only water of urban provisioning $\left(0.3 \mathrm{dS} \mathrm{m}^{-1}\right)$ for the good initial establishment of the transplanted plants. From transplanting to the end of the experiment, irrigations were performed manually, using a $1000 \mathrm{~mL}$ beaker.

The weekly ECw check was performed with the aid of a portable conductivity meter. The volume drained and the electrical conductivity of the drain (ECd) was estimated by collecting some samples 24 hours after irrigation. To determine the daily volume of water required, the following equation was used:

$V i=\frac{\mathrm{Va}-\mathrm{Vd}}{1-\mathrm{LF}}$

Where: $\mathrm{Vi}=$ Volume to be irrigated; $\mathrm{Va}=$ Volume applied; $\mathrm{Vd}=$ Volume drained after 24 hours of application; $\mathrm{LF}=$ Leaching factor $(10 \%)$.

We used a randomized block design with five repetitions of three plants, the treatments were characterized through the irrigation water with different electric $(\mathrm{CEa})$ conductivity $\left(0.3 ; 1.2 ; 2.1\right.$ and $\left.3.0 \mathrm{dS} \mathrm{m}^{-1}\right)$, constituting an experimental area of 60 plants. Plants were arranged in the crop row using East-West direction., in agreement with Rodrigues et al. (2013), spaced $1.5 \mathrm{~m}$ between lines and $1.0 \mathrm{~m}$ between plants.

Daily, with the aid of a thermohygrometer, the temperature $\left({ }^{\circ} \mathrm{C}\right)$ and air humidity $(\%)$ values were quantified at 60 DAT. Both data are expressed in Figure 1.

\section{Physiological analysis}

At 60 days after the transplant (DAT), was determined the leaf area through the measurement of the length (C) and width $(\mathrm{L})$ of all leaves of the plants, in agreement with Reis et al. (2013), being applied the following equation: $\mathrm{AF}=\mathrm{C} * \mathrm{~L} * \mathrm{f}$, where: $\mathrm{AF}$ - area to foliate $\left(\mathrm{m}^{2}\right) ; \mathrm{C}$ - length of the leaf $(\mathrm{m})$; L - width of the leaf $(\mathrm{m})$; and $\mathrm{f}$ - correction factor (0.59);

At 60 DAT, were evaluated the gaseous changes in intermediate leaves of plants of $P$. peruviana $\mathrm{L}$. with the aid of IRGA (InfraRed Gas Analyzer, LCi-SD), measuring 
the intercellular concentration expressed as $\mathrm{CO}_{2}(\mathrm{Ci}) \mu \mathrm{mol}$ $\left(\mathrm{CO}_{2}\right) \mathrm{m}^{-2} \mathrm{~s}^{-1}$, stomatal conductance $(\mathrm{gs})$ in $\mathrm{mol}\left(\mathrm{H}_{2} \mathrm{O}\right) \mathrm{m}^{-2} \mathrm{~s}$ ${ }^{1}$, transpiration $(E)$ in $\mathrm{mmol}\left(\mathrm{H}_{2} \mathrm{O}\right) \mathrm{m}^{-2} \mathrm{~s}^{-1}$ and the photosynthetic tax $(A) \mu \mathrm{mol}\left(\mathrm{CO}_{2}\right) \mathrm{m}^{-2} \mathrm{~s}^{-1}$, using these data was calculated the intrinsic efficiency in the use of water (EIUA) for the reason between $\mathrm{A}$ and $\mathrm{E},(E I U A=A / E)$ expressed in [ìmol $\left.\left(\mathrm{CO}_{2}\right) \mathrm{m}^{-2} \mathrm{~s}^{-1}\right]\left[\mathrm{mmol}\left(\mathrm{H}_{2} \mathrm{O}\right) \mathrm{m}^{-2} \mathrm{~s}^{-1}\right]^{-1}$ and the instantaneous efficiency of the carboxylation (EICi) becoming separated to $A$ for $C i(E I C i=A / C i)$ and expressed in $\left[\mathrm{mmol}\left(\mathrm{CO}_{2}\right) \mathrm{m}^{-2} \mathrm{~s}^{-1}\right]$ [ìmol $\left.\left(\mathrm{CO}_{2}\right) \mathrm{mol}^{-1}\right]^{-1}$ (Zeist et al., 2014; Barbosa et al., 2015).

For evaluation of cellular damages, the electrolytes extravasation technique was used (Bajji et al., 2001), being collected eight foliate disks with a diameter of $1.2 \mathrm{~cm}^{2}$ each, later transported to the Laboratory of Analyses of Seeds and Seedlings of the Federal University of Campina Grande, where it was washed immediately with distilled water seeking the removal of broken cells and other electrolytes adhered to the disks foliate.

After the washing, the disks were dried in a paper towel and put in beakers containing $25 \mathrm{ml}$ of distilled water at $25^{\circ} \mathrm{C}$, for $4 \mathrm{~h} 00 \mathrm{~min}$; after this period the electric $(\mathrm{C} 1)$ conductivity was measured with a bench conductivity meter (mCA 150) and the beakers with the disks were put in a kiln at $90{ }^{\circ} \mathrm{C}$, for $2 \mathrm{~h} 00 \mathrm{~min}$; afterward, after the temperature equalization, the maximum electric conducti-

Table 1: Chemical and physical composition of substrates used in the production of seedlings (SPM) and in the cultivation (SCV) of Physalis peruviana L. under different levels of irrigation water salinity and the chemical composition of irrigation water used in the cultivation of Physalis peruviana L. under different levels of irrigation water salinity

\begin{tabular}{|c|c|c|c|c|c|c|c|c|c|c|c|}
\hline \multicolumn{12}{|c|}{ Chemical and physical composition of substrates } \\
\hline & \multicolumn{2}{|c|}{ pH } & $\mathbf{P}$ & $\mathrm{S}_{-\mathrm{SO}_{4}}^{-2}$ & & $\mathbf{K}^{+}$ & $\mathrm{Na}^{+}$ & $\mathbf{H}^{+}+\mathbf{A l}^{+}$ & & $\mathbf{A l}^{+3}$ & $\mathbf{C a}^{+2}$ \\
\hline & \multicolumn{2}{|c|}{ Water $(1: 2.5)$} & \multicolumn{2}{|c|}{$\mathrm{mg} \mathrm{dm}^{-3}$} & \multicolumn{7}{|c|}{$\mathrm{cmol}_{\mathrm{c}} \mathrm{dm}^{-3}$} \\
\hline SPM & \multicolumn{2}{|c|}{5.5} & 257.30 & - & \multicolumn{2}{|r|}{2.00} & 0.43 & 8.57 & \multicolumn{2}{|r|}{0.05} & 2.69 \\
\hline SCV & \multicolumn{2}{|c|}{7.4} & 733.39 & - & & 2.73 & 1.20 & 0.00 & \multicolumn{2}{|r|}{0.00} & 1.23 \\
\hline & \multicolumn{2}{|c|}{$\mathrm{Mg}^{+2}$} & SB & CTC & & M.O. & Sand & Silt & \multirow{2}{*}{\multicolumn{2}{|c|}{ Clay }} & \multirow{2}{*}{$\begin{array}{c}\text { Textural } \\
\text { class }\end{array}$} \\
\hline & \multicolumn{4}{|c|}{$\mathrm{cmol}_{\mathrm{c}} \mathrm{dm}^{-3}$} & \multicolumn{4}{|c|}{$\mathrm{kg}^{-1}$} & & & \\
\hline$\overline{\mathrm{SPM}}$ & \multicolumn{2}{|c|}{1.46} & 3.89 & 12.46 & & 233.51 & 878 & 113 & & 9 & \multirow{2}{*}{$\begin{array}{c}- \\
\text { Frank sand }\end{array}$} \\
\hline SCV & \multicolumn{2}{|c|}{1.09} & 6.25 & 6.25 & & 10.34 & 789 & 155 & & 56 & \\
\hline \multicolumn{12}{|c|}{ Chemical composition of irrigation water } \\
\hline \multirow{2}{*}{ CEa } & \multirow{2}{*}{$\mathrm{pH}$} & $\mathbf{C a}^{+2}$ & $\mathbf{M g}^{+2}$ & $\mathbf{K}^{+}$ & $\mathrm{Na}^{+}$ & $\mathrm{CO}_{3}{ }^{2-}$ & $\mathrm{HCO}_{3-}$ & $\mathrm{Cl}^{-}$ & $\mathrm{SO}_{4}{ }^{2-}$ & CSR & \multirow{2}{*}{ RAS } \\
\hline & & \multicolumn{9}{|c|}{$\operatorname{mmol}_{c} \mathbf{L}^{-1}$} & \\
\hline 0.3 & 7.20 & 0.30 & 0.65 & 0.12 & 1.30 & 0.00 & 2.15 & 1.60 & 0.02 & 1.20 & 2.67 \\
\hline 1.2 & 6.33 & 3.05 & 2.50 & 0.67 & 3.90 & 0.00 & 6.20 & 6.20 & 0.00 & 0.65 & 3.31 \\
\hline 2.1 & 7.38 & 2.03 & 1.47 & 0.28 & 3.07 & 0.49 & 6.23 & 10.73 & 0.15 & 3.22 & 3.33 \\
\hline 3.0 & 8.60 & 2.75 & 1.25 & 0.05 & 4.01 & 1.48 & 10.34 & 24.40 & 0.44 & 7.82 & 4.01 \\
\hline
\end{tabular}

P, K, Na: Extractor Mehlich 1; SB: Sum of Exchangeable Bases; H + Al: Extractor Calcium Acetate 0.5 M, pH 7,0; CTC: Cation Exchange Capacity; Al, Ca, Mg: Extractor KCl 1 M; M.O.: Organic Matter - Walkley-Black.

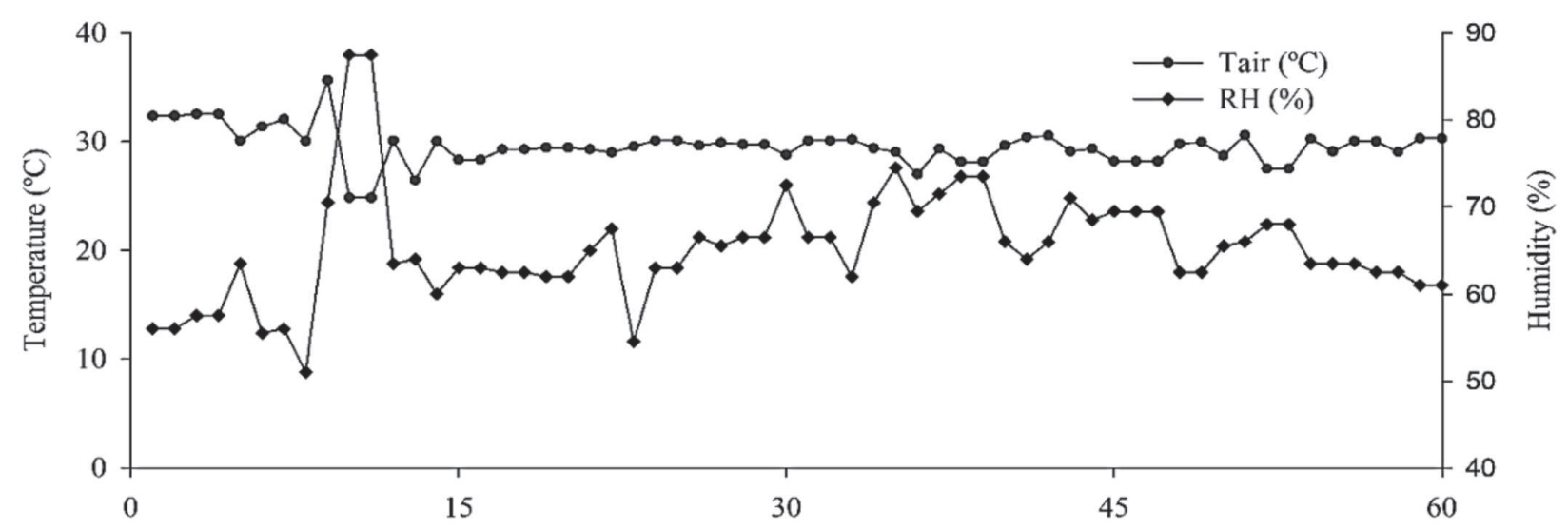

Days after transplanting (DAT)

Figure 1: Precipitation, average temperature (Tair), and average relative air humidity (Humidity - RH) during the cultivation of Physalis peruviana $\mathrm{L}$. 
vity was measured (C2) and the extravasation of electrolytes (EE) was calculated through the following equation: $\mathrm{EE}=(\mathrm{C} 1 / \mathrm{C} 2) \times 100$.

For the determination of chlorophyll content $\mathrm{a}, \mathrm{b}$ and carotenoids also eight foliate disks were collected, $1.2 \mathrm{~cm}^{2}$ each, coming from the medium third of each plant. The extraction of the pigments was accomplished by maceration with acetone $80 \%$ and $\mathrm{CaCO}_{3}$ in the darkness, being later filtered and completed up to $25 \mathrm{~mL}$ with acetone $80 \%$ and the readings were made with aid of a spectrophotometer in the wavelengths of $663 ; 645$ and $470 \mathrm{~nm}$. The results were calculated according to Lichtenthaler (1987) and expressed in grams by square meter of leaf blade $\left(\mathrm{g} \mathrm{m}^{-2}\right)$.

\section{Statistical analysis}

The data obtained was analyzed for normality (Shapiro Wilk test) and homoscedasticity (Hartley test) and, subsequently, subjected to analysis of variance ( $\mathrm{p} \mathrm{d}$ " 0.05 ) and, when significant, polynomial regression was applied at the level of $5 \%$ of probability, using the Sisvar 5.3 (Ferreira, 2011).

\section{RESULTS AND DISCUSSION}

In agreement with the summary of the variance analysis presented in Table 2, the unitary increase of the salinity of irrigation water did not significantly influenced $(\mathrm{p}<0.05)$ in the physiologic characteristics in plants of $P$. peruviana until 60 DAT, except for the variables extravasation of electrolytes and chlorophyll $\mathrm{a}$ and $\mathrm{b}$.

When evaluating the intracellular concentration of $\mathrm{CO}_{2}$ in plants of $P$. peruviana L., the average of $234.61 \mu \mathrm{mol}$ $\left(\mathrm{CO}_{2}\right) \mathrm{m}^{-2} \mathrm{~s}^{-1}$ presented in Table 2 were close to those observed by Silva et al. (2015), who obtained $244.87 \mu \mathrm{mol}$ $\mathrm{m}^{-2} \mathrm{~s}^{-1}$ when evaluating $C i$ in eggplant (Solanum melongena L.) plants at 100 DAT, using $66 \%$ more of the irrigation depth recommended for the culture; while Zeist et al. (2014) verified variation between 378.29 and 382.94 $\mu \mathrm{mol}\left(\mathrm{CO}_{2}\right) \mathrm{m}^{-2} \mathrm{~s}^{-1}$ in $P$. peruviana $\mathrm{L}$. cultivated in two atmospheres (greenhouse and field) at 86 DAT in the municipal district of Guarapuava, PR.

In a similar way, the unitary increase in CEa in levels up to $3.0 \mathrm{dS} \mathrm{m}^{-1}$ did not promote alterations in the stomatal conductance (Gs) in plants of $P$. peruviana L. to 60 DAT, probably in the function of the osmotic adjustment during the growth of the plants, however, it could commit productive aspects. Climatic factors such as the high temperature at the time of the assessment (10:00 a.m.) and a certain water limitation may have contributed to the achievement of these results. However, the natural process would be for the plants to show differences in stomatal conditions due to the increase in saline levels.

According to Kerbauy (2012), the capacity of some plants in regulating the stomatal opening and the transpiration, associated with assimilation of $\mathrm{CO}_{2}$, is influenced by factors as hydric availability in the soil, air humidity, and temperature.

The verification of stomatal conductance in plants of Physalis peruviana becomes valid because, through this variable, it is possible to evaluate the $\mathrm{CO}_{2}$ influx in the substomatal cavity and the $\mathrm{O}_{2}$ efflux as a byproduct of the photosynthesis, so that, as larger is the stomatal opening great will be the $\mathrm{CO}_{2}$ diffusion (Silva et al., 2015).

In agreement with stomatal conductance and transpiration data (Table 2), it is verified that there was no reduction in the loss of water for the atmosphere due

Table 2: Summary of the variance analysis for the variables foliate area (AF), intercellular concentration of $\mathrm{CO}_{2}(\mathrm{Ci})$, stomatal conductance $(G s)$ transpiration $(E)$, photosynthetic rate $(A)$, intrinsic efficiency in the use of water $(E I U A)$, instantaneous efficiency of the carboxylation (EICi), extravasation of electrolytes (EE), chlorophyll a $(\mathrm{Ca})$, chlorophyll $\mathrm{b}(\mathrm{Cb})$ and carotenoids $(\mathrm{Carot})$ in plants of $P$. peruviana L. at 60 DAT, under different levels of salinity of the irrigation water

\begin{tabular}{|c|c|c|c|c|c|}
\hline & \multicolumn{5}{|c|}{ Middle square } \\
\hline & Salinity & Block & Error & Average & CV\% \\
\hline$A F$ & $0.002^{\mathrm{ns}}$ & 0.001 & 0.003 & 0.27 & 20.23 \\
\hline$C i$ & $124.355^{\mathrm{ns}}$ & 76.089 & 57.704 & 234.61 & 3.24 \\
\hline$E$ & $0.043^{\mathrm{ns}}$ & 0.723 & 0.064 & 1.69 & 14.97 \\
\hline Gs & $0.000^{\mathrm{ns}}$ & 0.000 & 0.000 & 0.09 & 16.11 \\
\hline$A$ & $0.270^{\mathrm{ns}}$ & 0.809 & 0.235 & 6.60 & 7.35 \\
\hline EIUA & 0.629 ns & 1.341 & 0.126 & 3.72 & 9.56 \\
\hline$E I C i$ & $0.000^{\mathrm{ns}}$ & 0.000 & 0.000 & 0.03 & 12.73 \\
\hline$E E$ & $116.611^{* * *}$ & 3.239 & 4.609 & 11.34 & 18.92 \\
\hline $\mathrm{Ca}$ & $0.065^{* *}$ & $0.045^{*}$ & 0.009 & 1.38 & 6.96 \\
\hline $\mathrm{Cb}$ & $0.006^{* *}$ & $0.004^{*}$ & 0.000 & 0.42 & 6.75 \\
\hline Carot & $0.003^{\mathrm{ns}}$ & $0.004^{\mathrm{ns}}$ & 0.002 & 0.32 & 14.32 \\
\hline
\end{tabular}

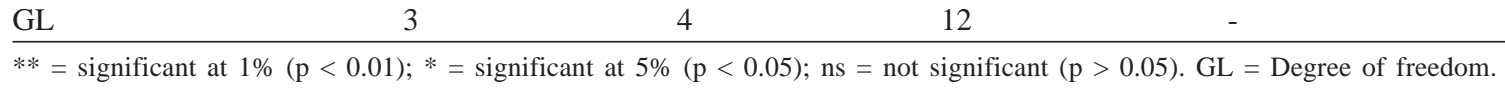

Rev. Ceres, Viçosa, v. 68, n.6, p. 617-623, nov/dec, 2021 
to saline effects, it could be resulting from the temperature oscillation (Figure 1) and hydric availability in the soil. Therefore, as reported by Silva et al. (2015), the reduction in the hydric availability can cause stomatal closing, limiting the stomatal conductance and the transpiration, which reduces, consequently, the photosynthetic rate.

Considering the evapotranspiration of the culture (ETc), plants of Solanum melongena L. that received $59.48 \%$ more water, in relation to ETc, resulted in values of stomatal conductance equal to $0.24 \mathrm{~mol}^{\circ} \mathrm{H}_{2} \mathrm{O} \mathrm{m}^{-2} \mathrm{~s}^{-1}$ at 100 DAT (Silva et al., 2015), therefore, greater than these observed in this work. These results are evidence that is necessary to reduce the irrigation intervals, which means apply water more frequently and in the same volume when plants of $P$. peruviana are in the flowering period, which starts at 45 DAT.

When evaluating the results obtained for photosynthesis in plants of $P$. peruviana (Table 2) the average of $6.60 \mu \mathrm{mol}\left(\mathrm{CO}_{2}\right) \mathrm{m}^{-2} \mathrm{~s}^{-1}$ can be considered low in agreement with 17.2 and $24.7 \mathrm{imol}\left(\mathrm{CO}_{2}\right) \mathrm{m}^{-2} \mathrm{~s}^{-1}$ found by Flores (2007) when evaluating different tomato accesses in greenhouse conditions, in Viçosa, MG. However, the shading proportionated by the number of leaves and, consequently, the leaf area $\left(0.27 \mathrm{~m}^{2}\right)$ could have limited the photosynthetic rate in $P$. peruviana at 60 DAT, because, according to Zeist et al. (2014), protected atmospheres as greenhouse provide increments in the speed of leaves expansion, mainly, due to high temperature and relative humidity conditions

To evaluate the influence of the number of leaves and the foliate area in cultures as Solanum lycopersicum (Reis et al., 2013; Moura et al., 2017) and Solanum melongena L. (Lima et al., 2015) researches were carried out with the intention of predicting agronomic values and adaptations in cultivated plants, creating relations among the number of leaves, the leaf area, and photosynthetic efficiency. Reis et al. (2013) explain that the leaf area can provide a larger use of solar energy, capturing photons and using them in photosynthetic processes and in the translocation of photoassimilates. However, according to results observed by Zeist et al. (2014), the cultivation environment can be a limiting factor for this variable.

Regarding the intrinsic efficiency in the use of water (Table 2), which represents the reason between the amount of assimilated $\mathrm{CO}_{2}$ and the water perspired by the plant, it was verified that the different studied saline levels did not provide significant differences for this characteristic in plants of $P$. peruviana L. at 60 DAT, suggesting certain tolerance to the saline stress as a consequence of the growing levels of CEa. Besides, the reason between the photosynthetic tax and the intracellular concentration of $\mathrm{CO}_{2}$ suggests poor assimilation of $\mathrm{CO}_{2}$ and accumulation of reserves in the plant because there was low photosynthesis to the detriment of the high intracellular concentration of $\mathrm{CO}_{2}$ (Table 2).

Lima et al. (2015) mention that some morphologic alterations in plants happen due to hydric, nutritional, and hormonal imbalance, then influencing in the stomatal leaf closing and reduction in the transpiration and absorption of water. However, in agreement with Souza et al. (2011), the ions accumulation in the vacuoles, as well as of organic solutes, allow the hydric potential gradient maintenance, resulting in the translocation of water by the plant's root to the aerial part.

Some plants can accumulate salts inside their cells, while others can exclude $\mathrm{Cl}^{-}$from the root system, or accumulate these ions in the cell vacuole, as well as reducing photosynthetic rate, water absorption, or increasing osmotic potential. In addition, there may have been mechanisms for the exclusion of the element's sodium and chlorine in some morphophysiological structures in $P$. peruviana L. When the extravasation of electrolytes was evaluated in plants of $P$. peruviana L. (Figure 2A) it was verified that the unitary increase in CEa resulted in the increment of 70.88 percentile points among to smallest and the largest saline concentration, which were observed the occurrence of cellular damages in relation to the plants that received saline water. Therefore, high levels of salinity applied in the irrigation of plants of $P$. peruviana L. can damage essential structures of the cells, mainly of the plasmatic membrane.

In agreement with Langaro et al. (2014) the extravasation of electrolytes is the last stage observed in function of the oxidative stress, suggesting that there were a breaking of the cellular membrane, so that, the greater is the accumulation of ions in the vacuoles greater will be the cellular extravasation, which implicates, indirectly, in leaves of larger thickness and dark coloration, affecting the chlorophyll contents a and b (Figure 2B). In this way, the capacity of accumulate salts absorbed by the roots and translocate to the leaves does the $P$. peruviana $\mathrm{L}$. a plant considered tolerant at saline levels up to $3.0 \mathrm{dS} \mathrm{m} \mathrm{m}^{-1}$.

Regarding the chlorophyll content a and b (Figure 2B), it was observed growing linear effect significant for both variables, with an increase of 7.56 and 8.17 percentile points for the chlorophyll values a and b $(\mathrm{Ca}$ and $\mathrm{Cb})$, respectively, when it was used growing levels until $3.0 \mathrm{dS}$ $\mathrm{m}^{-1}$ in CEa until 60 DAT (Figure 2B). The results observed for chlorophyll values a and $\mathrm{b}$ do not corroborate with the statements by Freire et al. (2013), where plants exposed to the salinity of the irrigation water tend to reduce the chlorophyll contents in reason of the enzyme chlorophyllase increase, which degrades the molecules of this pigment. 

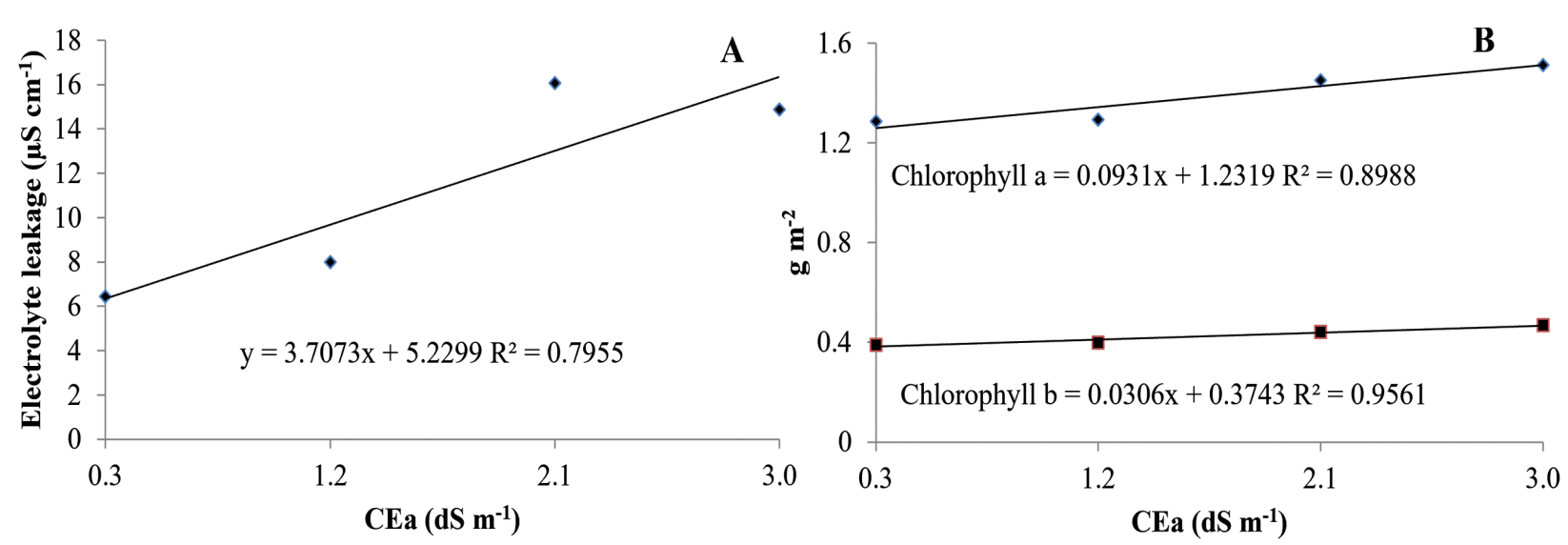

Figure 2: Extravasation of electrolytes (A) and chlorophyll a and b (B) in P. peruviana L. plants under different levels of irrigation water salinity at 60 DAT.

The contents of $\mathrm{Ca}, \mathrm{Cb}$, and carotenoids may have been affected due to the $\mathrm{pH}$ and to the content of $\mathrm{K}^{+}$in the water (Table 1) and in the soil (Table 1), causing the competitive inhibition of the nutrient $\mathrm{Mg}^{2+}$, because it acts in the plant as a cofactor of enzymes phosphorylating, forming a bridge between the pyrophosphate of ATP or ADP and the enzyme's molecule, and, consequently, in the photosynthesis (Taiz et al. 2017).

According to Lima et al. (2012) the chlorophyll a and b are hydrophobic structures, therefore, insoluble in water, and their main function is to convert luminous energy into chemical energy, a process that happens in the chloroplasts, while the carotenoids are pigments liposoluble with yellow-orange coloration, which can be less visible due to presence of chlorophyll a and $b$, also considered as antioxidants, which explains the no significant results $(\mathrm{p}<0.05)$ for carotenoids contents, expressed in Table 2.

\section{CONCLUSIONS}

With the results obtained in this work, it can be concluded that Physalis peruviana L. is a species tolerant to salinity in levels up to $3.0 \mathrm{dS} \mathrm{m}^{-1}$ and that it develops mechanisms such as reduction in stomatal activity, sweating, and photosynthesis without presenting significant effect in the evaluated physiological characteristics until 60 DAT, except for the variables extravasation of electrolytes and chlorophyll $\mathrm{a}$ and $\mathrm{b}$.

\section{ACKNOWLEDGMENTS}

Our thanks to the Ministério da Educação for granting the scholarship for the agronomy tutorial education program (UFCG) for granting scholarships to the participants in this study.

The authors declare that there is no conflict of interest.

\section{REFERENCES}

Acosta-Motos JR, Ortuño MF, Bernal-Vicente A, Diaz-Vivancos P, Sanchez-Blanco MJ \& Hernandez JA (2017) Plant responses to salt stress: adaptive mechanisms. Agronomy, 7:1-38.

Bajji M, Kinet JM \& Lutts S (2001) The use of the electrolyte leakage method for assessing cell membrane stability as a water stress tolerance test in durum wheat. Plant Growth Regulation, $36: 1-10$.

Barbosa RCA, Leite RP, Soares Filho WS, Figueiredo LC \& Silva JG (2015) Trocas gasosas de híbridos de tangerineira Sunki com Citrumelo Swingle sob estresse salino. In: III Inovagri International Meeting, Fortaleza. Proceedings. p.3202-3212

Campos VB \& Cavalcante LF (2009) Salinidade da água e biofertilizante bovino: Efeito sobre a biometria do Pimentão. Holos, 2:10-20.

Deinlein U, Stephan AB, Horie T, Luo T, Xu G \& Schroeder J (2014) Plant salt-tolerance mechanisms. Trends in Plant Science, 19:371-379.

Dias NS \& Blanco FF (2010) Efeitos dos sais no solo e na planta. In: Gheyi HR, Dias NS \& Lacerda CF (Eds.) Manejo da salinidade na agricultura: estudos básicos e aplicados. Fortaleza, INCTSal. p.129-141.

Ferreira DF (2011) Sisvar: a computer statistical analysis system. Ciência e agrotecnologia, 35:1039-1042.

Flores MEP (2007) Variabilidade genética de acessos de tomateiro (Lycopersicon esculentum Mill.) com base na avaliação de fotossíntese, partição de fotoassimilados e produção. Master Dissertation. Universidade Federal de Viçosa, Viçosa. $48 \mathrm{p}$.

Flowers TJ \& Colmer TD (2015) Plant salt tolerance: Adaptations in halophytes. Annals of Botany, 115:327-331.

Freire JLO, Cavalcante LF, Nascimento R \& Rebequi AM (2013) Teores de clorofila e composição foliar do maracujazeiro irrigado com águas salinas e biofertilizante. Revista de Ciências Agrárias, 36:57-70.

Ianckievicz A, Takahashi HW, Fregonezi GAF \& Rodini FK (2013) Produção e desenvolvimento da cultura de Physalis L. submetida a diferentes níveis de condutividade elétrica da solução nutritiva. Ciência Rural, 43:438-444.

Kerbauy GB (2012) Fisiologia vegetal. $2^{\text {nd }}$ ed. Rio de Janeiro, Guanabara Koogan. 431p. 
Langaro AC, Nohatto MA, Perboni LT, Tarouco CP \& Agostinetto D (2014) Alterações fisiológicas na cultura do tomateiro devido à deriva simulada de herbicidas. Revista Brasileira de Herbicidas, $13: 40-46$

Lichtenthaler HK (1987) Chlorophylls and carotenoids: pigments of photosynthetic biomembranes. In: Packer L \& Douce R (Eds.) Meth Enzimol, 148. Freiburg, Academic Press. p. 350-382.

Lima CSM, Manica-Berto R, Silva SJP, Betemps DL \& Rufato AR (2009) Custos de implantação e condução de pomares de Physalis na região sul do estado do Rio Grande do Sul. Revista Ceres, $56: 555-561$.

Lima GPP, Borges LS, Manoel L, Fleuri LF \& Vieira MCS (2012) Pigmentos e teor de água em espinafres orgânicos e convencionais. Horticultura Brasileira, 30:7353-7357.

Lima LA, Oliveira FA, Alves RC, Linhares PSF, Medeiros AMA \& Bezerra FMS (2015) Tolerância da berinjela à salinidade da água de irrigação. Revista agro@mbiente, 9:27-34

Melo APC, Fernandes PM, Silva-Neto CM \& Seleguini A (2017) Solanáceas em sistema orgânico no Brasil: tomate, batata e physalis. Scientia Agopecuaria, 3:279-290.

Melo HF, Souza ER \& Cunha JC (2017) Fluorescence of chlorophyll a and photosynthetic pigments in Atriplex nummularia under abiotic stresses. Revista Brasileira de Engenharia Agrícola e Ambiental, 21:232-237.

Moura MSB, Souza LSB, Oliveira LDS, Silva TGF \& Yuri JE (2017) Biometria e eficiência do uso da água em tomate cereja no semiárido. Agrometeoros, 25:163-171.

Muniz J, Kretzschmar AA, Rufato L, Pelizza TR, Marchi T, Duarte AE, Lima APF \& Garanhani F (2011) Sistemas de condução para o cultivo de Physalis no planalto catarinense. Revista Brasileira de Fruticultura, 33:830-838.

Muniz J, Marchi T, Coldebella MC, Rufato L \& Kretzschmar AA (2015) Crescimento vegetativo e potencial produtivo de fisális. Revista de Ciências Agroveterinárias, 14:15-23.
Puente LA, Pinto-Munoz CA, Castro ES \& Cortés M (2011) Physalis peruviana Linnaeus, the multiple properties of highly functional fruit: A review. Food Research International, 44:17331740 .

Reis LS, Azevedo CAV, Albuquerque AW \& Souza Júnior JF (2013) Índice de área foliar e produtividade do tomate sob condições de ambiente protegido. Revista Brasileira de Engenharia Agrícola e Ambiental, 17:386-391.

Rodrigues FA, Penoni ES, Soares JDR, Silva RAL \& Pasqual M (2013) Caracterização fenológica e produtividade de Physalis peruviana cultivada em casa de vegetação. Bioscience Journal, 29:1771-1777.

Silva FG, Dutra WF, Dutra AF, Oliveira IM, Filgueiras LMB \& Melo AS (2015) Trocas gasosas e fluorescência da clorofila em plantas de berinjela sob lâminas de irrigação. Revista Brasileira de Engenharia Agrícola e Ambiental, 19:946-952.

Silva JG, Lopes KP, Paiva FJS, Rodrigues MHBS \& Nobrega JS (2018) Effect of the Substrate and Containers in the Initial Growth of Seedlings of Physalis peruviana L. Journal of Agricultural Science, 10:314-320.

Silva VPR, Pereira ERR, Azevedo PV, Sousa FAZ \& Sousa IF (2011) Análise da pluviometria e dias chuvosos na região Nordeste do Brasil. Revista Brasileira de Engenharia Agrícola e Ambiental, 15:131-138.

Souza MO, Souza CLM \& Pelacani CR (2011) Germinação de sementes osmocondicionadas e não osmocondiconadas e crescimento inicial de Physalis angulata L. (Solanaceae) em ambientes salinos. Acta Botânica Brasílica, 25:105-112.

Taiz L, Zeiger E, Møller IM \& Murphy A (2017) Fisiologia vegetal. $6^{\text {th }}$ ed. Porto Alegre, Artmed. 888p.

Zeist AR, Zanin DS, Chagas RR, Giacobbo CL \& Resende JTV (2014) Produtividade, desenvolvimento vegetativo e trocas gasosas de Physalis peruviana L. cultivado em ambiente protegido e a campo. Enciclopédia Biosfera, 10:4015-4023. 